<総 説 $>$

\title{
デンドリマーの表面改質による細胞・組織接着制御 Control of Cell and Tissue Adhesion by Surface Modification of Dendrimers
}

\section{1.はじめに}

著者は，機能性のバイオマテリアルの創製をメインに行っ ている研究者である。本誌名である「Adhesion」は，バ イオ分野では cell adhesion（細胞接着：細胞が他の細胞 や基材に接着すること), focal adhesion（接着斑：細胞 と基材の接着点でみられる蛋白質の集積構造）などで頻繁 に使用されている耳なじみの言葉であるが，日本接着学会 に所属しておられる多くの方は, 非バイオの分野で研究さ れているであろうと思われる。本稿では, 生体分野におけ る接着制御の意義やその手法に関して, 著者が行ってきた 研究を中心に紹介させていただこうと思う。

\section{2. デンドリマー}

著者は，デンドリマーという合成高分子の表面を加工す ることで様々な機能性バイオマテリアルを作製してきた。 デンドリマーは特徵的な高分子化合物であり, 機能性材料 として様々な研究が行われている。デンドリマー1 3) は, 核となるコア分子から段階的に世代数を増加させていくこ とによって分岐鎖を成長させていくため, 合成高分子であ るにも関わらず分子量が単一である。また，その末端に存 在する多数の反応性官能基や内部空間を利用して，様々な 機能性物質および生理活性物質を共有結合むしくは非共有 結合を介して付与することができる（図 1)。市販されて いるポリアミドアミン（PAMAM）デンドリマーの世代 数と粒径および末端官能基数の関係 ${ }^{3)}$ を表 1 に示す。世 代数が一つ増加するにつれて末端数は二倍に増加する。ま

$*$ 大阪府立大学大学院工学研究科

大阪府堺市中区学園町 1-1 $\quad$ 个 599-8531

Department of Applied Chemistry, Graduate School

Engineering, Osaka Prefecture University

1-1 Gakuen-cho, Naka-ku, Sakai, Osaka 599-8531, Japan

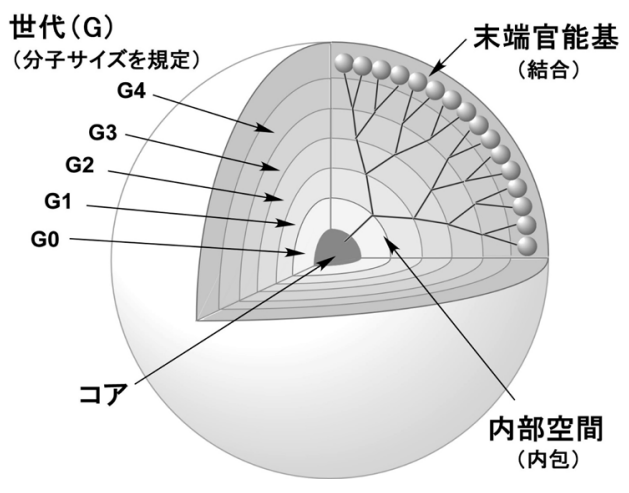

図 1 デンドリマー

た，分子量も約二倍となり，粒径は $1 \mathrm{~nm}$ 程度増加する。 このように構造やサイズを精密に制御できるデンドリマー はドラッグデリバリーシステム (DDS) やイメージング などのナノメディシン2 6) に利用することができる。 DDS 分野において, 用いる材料と細胞や組織との接着制 御は極めて重要である。すなわち，標的となる細胞や組織 には接着して, 取り込まれる必要があるが, それ以外の細 胞や組織との接着は副作用の原因となるため, 阻害しなけ ればならない。これを実現するためには，標的細胞・標的 組織を的確に認識して, 応答するシステムを組み込むこと が必要である。本稿では，デンドリマーと細胞や組織との

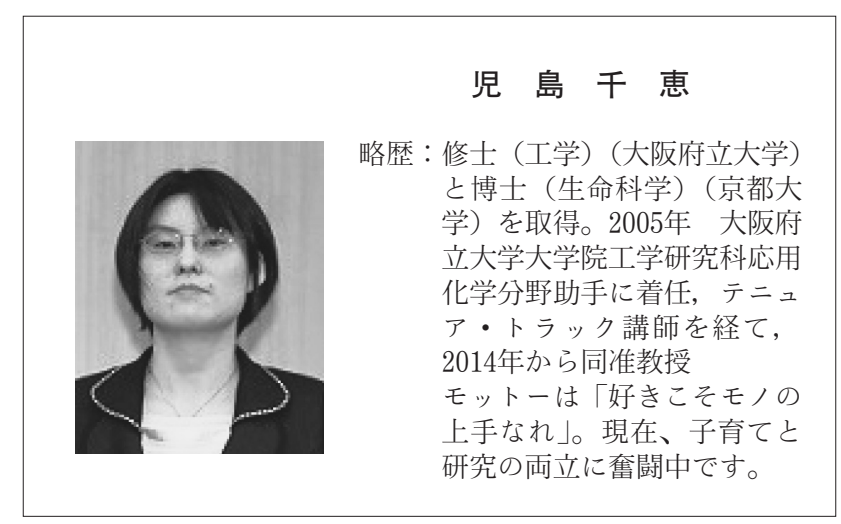


表 1 PAMAM デンドリマーの世代数増加の影響

\begin{tabular}{c|c|c|c}
\hline 世代 & 末 端 基 数 & 分子量 $(\mathrm{Da})$ & 粒 径 $(\mathrm{nm})$ \\
\hline \hline G 0 & 4 & 517 & 1.5 \\
\hline G 1 & 8 & 1,430 & 2.2 \\
\hline G 2 & 16 & 3,256 & 2.9 \\
\hline G 3 & 32 & 6,909 & 3.6 \\
\hline G 4 & 64 & 14,215 & 4.5 \\
\hline G 5 & 128 & 28,826 & 5.4 \\
\hline G 6 & 256 & 58,048 & 6.7 \\
\hline G 7 & 512 & 116,493 & 8.1 \\
\hline
\end{tabular}

相互作用について記載し，その相互作用を制御するための デンドリマーの表面改質に関する研究成果について紹介す る。

\section{3. デンドリマーと細胞・組織との相互作用}

細胞の最外層は脂質と蛋白質によって形成される細胞膜 である。細胞膜の外側にある脂質や蛋白質には負電荷をも つ糖鎖が結合しているため, 細胞は負電荷を帯びている。 したがって，正電荷を帯びているナノ粒子は細胞表面に非 特異的に吸着する7)ことが知られている。これは, デンド リマーに拈いても同様であり，アミノ末端のデンドリマー は細胞之相互作用しやすいこと ${ }^{8)}$ が報告されている。しか し，このようなアミノ末端のデンドリマーは細胞と相互作 用しやすい一方でその毒性む強い。さらに，非特異的な相 互作用であるため，目的の細胞への選択的な取り込みを実 現することはできない。また，血中に存在するアルブミン などの負電荷の蛋白質と凝集体を形成してしまい，単一分 子として機能しないことが懸念される。

培養ディッシュ上で行う細胞レベルの実験（in vitro 実 験）では，デンドリマーと細胞との相互作用について考慮 するだけでよいが，モデル動物を用いた実験（in vivo 実 験）では，細胞との接着だけでなく，その体内分布や組織 浸透性についても考慮する必要がある。デンドリマーの体 内分布はその投与方法によって大きく異なる。投与方法之 しては，経口投与，経皮投与，静脈投与，皮下投与などが ある。経口投与や経皮投与は自宅で簡便に投薬できる方法 であるが，皮膚や消化器官から血液へと移行し，患部に到 達して初めて生理機能を発現する。それぞれの移行段階で ロスが生じるため，多量の薬剤を投与する必要がある。抗 ガン剂は副作用が極めて強いため, その多くは直接血液に 注入する静脈投与が適用される。静脈投与の場合, 薬物運 搬体は血管壁を透過して，患部組織の内部にまで浸透する

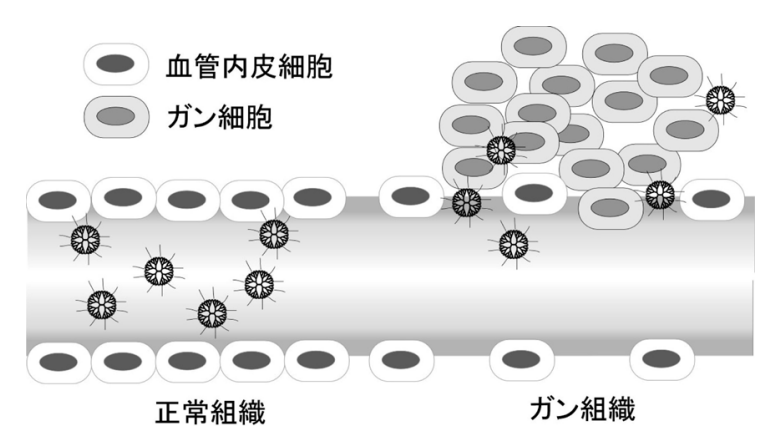

図 2 EPR 効果

必要がある。血中滞留性の高い高分子化合物がガン組織に 集積する現象が知られており， Enhanced Permeability and Retention (EPR) 効果 ${ }^{7,9}$ と呼ばれている。これは, 腫瘍が成長する際に形成される新生血管の血管壁が通常の 血管壁より屯漏洩しやすいこと（図 2)，ガン組織の周辺 には物質の排泄機構であるリンパ管が発達しにくいことに 起因している。また, 最近の研究より, ガン組織の深部に まで到達するには，粒径の小さい $50 \mathrm{~nm}$ 程度のナノ粒子が 有用であること ${ }^{10)}$ が明らかとなった。また，様々な世代 数のデンドリマーを用いた研究から $4 \mathrm{~nm}$ 程度以下のデン ドリマーは腫瘍部分には集積しないが，それ以上の粒径の デンドリマーは腫瘍部分に集積すること ${ }^{11)}$ が報告されて いる。リポソームやエマルションなどの粒径は一般に $100 \mathrm{~nm}$ 程度から数 $\mu \mathrm{m}$ であるが，デンドリマーは数 $\mathrm{nm}$ の粒子 であるため, 高い組織浸透性を有し, ガン組織の内部にま で到達することができると考えられる。したがって，分子 量が単一であるデンドリマーは, その分子量制御によって ガン組織への標的指向性や高い組織浸透性を付与すること ができるため, ガン治療のための薬物運搬体として有用で ある。しかし，上記に記載したカチオン性のアミノ末端デ ンドリマーは，非特異的に細胞之相互作用するため，目的 の組織に到達する前に, 他の細胞に捕捉されてしまう。し たがって, 細胞や組織との接着を精密に制御するデンドリ マーの設計が不可欠である。

\section{4. ポリエチレングリコール (PEG) 修飾デンドリマー}

\subsection{PEG 修飾による非特異吸着の抑制}

ポリエチレングリコール (PEG) は高い水溶性と排除体 積効果，そして生体適合性を有する高分子である。ナノ粒 子に PEG を修飾することによって，様々な蛋白質や細胞 との非特異的な吸着を抑制できること7,12) が知られている。 したがって，PEG 修飾デンドリマーは薬物運搬体として 有用である。そこで，我々はPEGモノメチルエーテル （2kDa）の水酸基にクロロギ酸-4-ニトロフェニルを反応 させることでアミノ基に反応する PEGを合成した。続い て，これを第 4 世代 (G4) の PAMAM デンドリマーの末 端アミノ基に反応させた。NMR 解析により，デンドリマー 


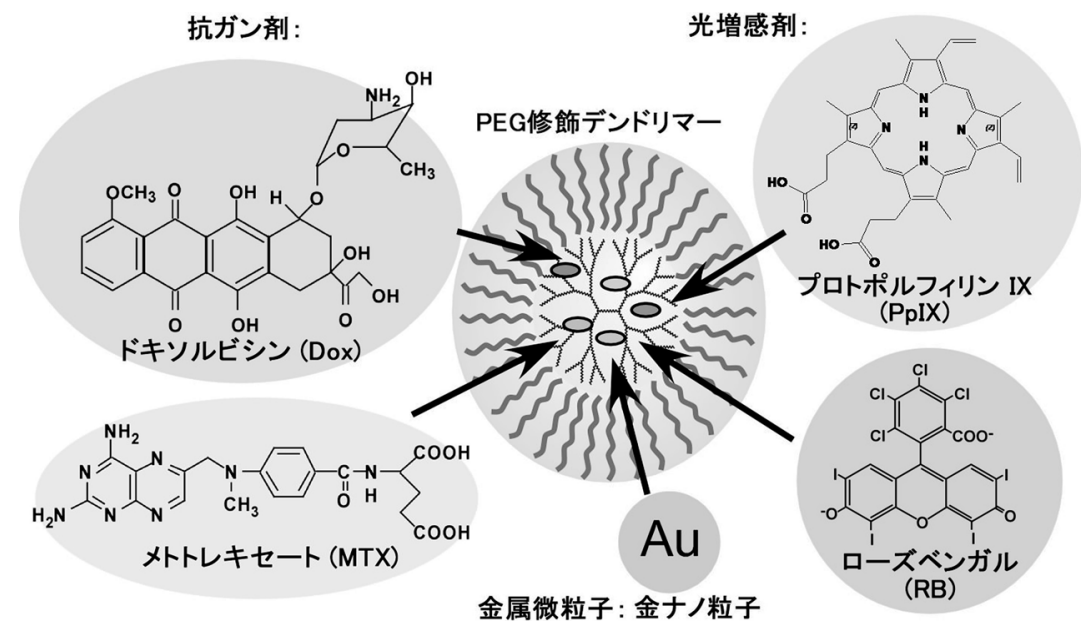

図 3 PEG デンドリマーに内包される様々な物質

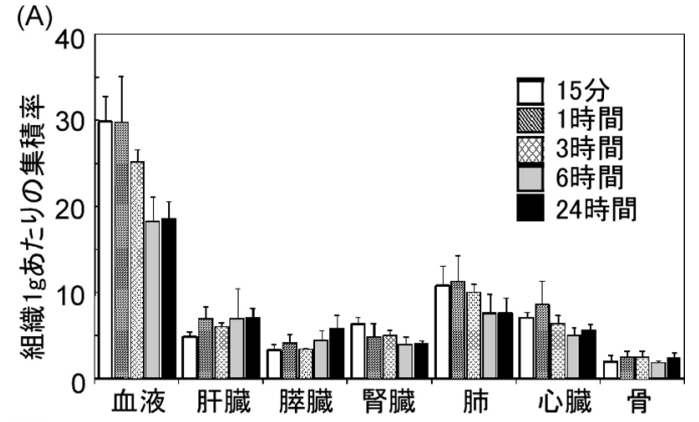

(B)

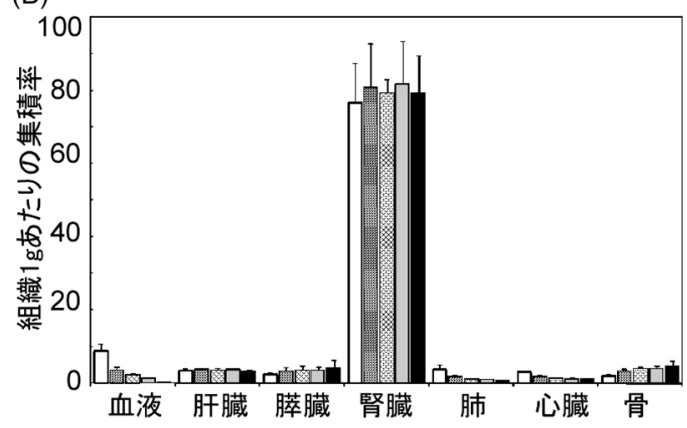

図 4 血中に投与した PEG 修飾デンドリマー（A）と PEG 未修飾デンドリマー（B）の体内動態

の全ての末端に PEG が結合できたこと ${ }^{13)}$ がわかった。さ らに，図 3 に示すような様々な生理活性物質を担持した PEG 修飾デンドリマー13 16) を作製することができた。ま た，PEG未修飾デンドリマーを血中に投与すると，腎臓 への集積が見られたのに対して, PEG 修飾デンドリマー を血中に投与すると，血液に残存する傾向が見られた（図 4)。このように，デンドリマーへの PEG 導入によって， 血中滞留性が著しく向上したこと ${ }^{17)}$ がわかった。上記の と抢り，ガン治療に抢いては，血中滞留性が高い高分子化 合物は EPR 効果によってガン組織への集積が期待される ため, PEG 修飾デンドリマーはガン治療のための薬物運 搬体として有用である。

\subsection{PEG 修飾デンドリマーの標的細胞への接着}

上記のとおり, PEG 修飾デンドリマーは細胞や蛋白質 との非特異的な吸着を抑制することができるため, その血 中滞留性を向上させることができる。しかし，同時に標的 細胞との吸着屯抑制されてしまうため, 細胞の取り込みも 低下してしまう。この現象は PEG ジレンマ ${ }^{18)}$ と言われて いる。これを解決するためには, 標的分子と特異的に結合 するリガンドの導入が有効である。例えば，ガン細胞はト ランスフェリンという蛋白質を取り込むことができるトラ ンスフェリンレセプター（受容体）を多く発現している。 したがって, トランスフェリンを結合した PEG 修飾デン ドリマーはガン細胞に効果的に取り込まれることが期待さ れる。Huang ら ${ }^{19)}$ はこのようなデンドリマーを作製し， ガン細胞への高効率なデリバリー効果を示した。トランス フェリンの分子量は $80 \mathrm{kDa}$ であり, 一般的なデンドリマー の分子量と同程度かそれよりあ大きい（表 1)。したがっ て，デンドリマーの表面に結合するには低分子リガンドの 方が適している。そこで, Han ら ${ }^{20)}$ はトランスフェリン セレプターに結合するペプチドを結合した PEG 修飾デン ドリマーを作製し，トランスフェリンを高発現している ガン細胞への選択的なデリバリーを示した。一方，葉酸 と結合する葉酸レセプターあある種のガン細胞で高発現し ていることが知られており, 葉酸もガン細胞のリガンドと して用いることができる。 Singh ら ${ }^{21)}$ は葉酸を結合した PEG 修飾デンドリマーを作製し，葉酸レセプターを高発 現している MCF7 細胞に対する選択的なデリバリーに成 功した。以上のように, PEG 修飾デンドリマーに適切な リガンドを付与することで, 非特異的な吸着を抑制し，標 的細胞に対する選択的なデリバリーを実現することができ る。

\section{5. 温度応答性デンドリマー}

何らかの刺激に応答する刺激応答性材料は, 患部に運搬 


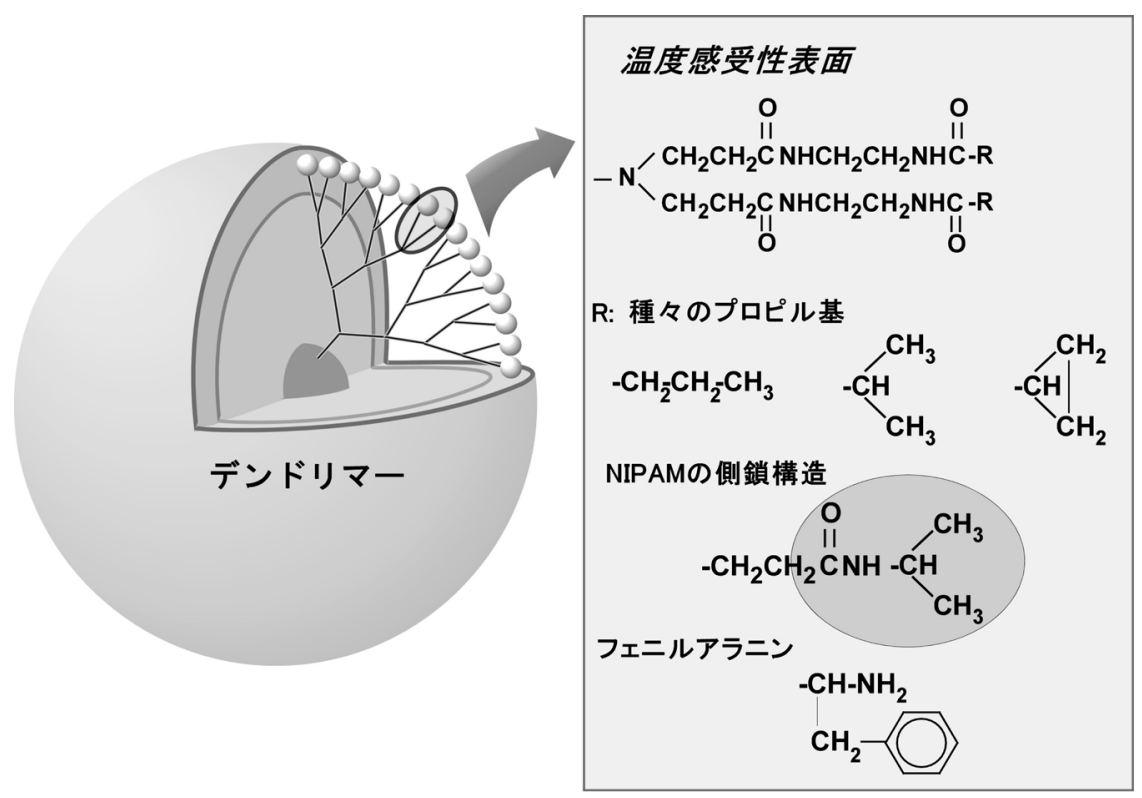

図 5 様々な温度応答性デンドリマー

体を集積させたり，患部において選択的に薬物を放出する システムの構築に利用することができる。ヒトの体温は $37^{\circ} \mathrm{C}$ 程度の定温であるため，ハイパーサーミアと呼ばれる 装置を用いて局所的に加温することで，体内での温度分布 を生じさせることができる。このため, DDS 分野では様々 な温度応答性ナノ粒子に関する研究 7,22$)$ が行われている。 本節では, 温度応答性デンドリマーの設計とそのバイオ応 用について紹介する。

\section{1 温度応答性デンドリマーの設計}

温度応答性高分子の代表例としてポリ（N-イソプロピ ルアクリルアミド) $(\operatorname{poly}(\mathrm{NIPAM}))$ が知られている。 木村ら ${ }^{23)}$ はデンドリマーの末端を開始点として重合によ り poly(NIPAM) を導入することにより, 温度応答性デ ンドリマーの作製を行った。一方，河野らのグループでは poly (NIPAM) の部分構造である NIPAM 基をデンドリ マーの末端に導入するだけで温度応答性デンドリマーを作

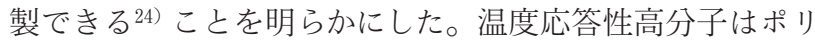
マー鎖に結合した水分子の脱水和が駆動力として作用する ことが知られているが，興味深いことに，上記の NIPAM 化デンドリマーでは相転移温度付近での大きな脱水和は 観察されなかった。また，デンドリマーに結合させる温 度応答性部位の構造を変化させることで, 温度応答性デン ドリマーの相転移温度を変化させることができた ${ }^{25)}$ 。 これは，末端に結合する化合物によって，デンドリマーの 親疎水性のバランスが变化したためであると考えられる。 さらに，デンドリマーの化学構造だけでなく，デンドリマー への内包物によっても相転移温度を変化させることができ た ${ }^{26)}$ 。

バイオ応用をするためには，生体由来物質を末端に有す
る温度応答性デンドリマーの作製が有用である。側鎖にフェ ニル基を有するアミノ酸であるフェニルアラニンを結合さ せたデンドリマーも温度応答性を示すことがわかった。イ ソロイシンやロイシンを結合したデンドリマーでは温度応 答性は見られなかったことから，フェニルアラニンが適切 な疎水性を持っている分子であることが示唆された ${ }^{27)}$ 。 以上のように，デンドリマーに温度応答性高分子やその部 分構造を結合させたり，もしくは，適切な疎水性を有する 化合物を結合させることで, 温度応答性デンドリマーを作 製できることが明らかとなった（図 5)。

\section{2 温度応答性エラスチンデンドリマーによる細胞へ の取り込み制御}

著者らは温度応答性蛋白質であるエラスチンに着目し， これを模倣したエラスチンデンドリマーの作製も行った。 エラスチンにはバリンープロリンーグリシンーバリンーグ リシン (VPGVG) の繰り返し配列がみられ，このペプチ ドはエラスチン様ペプチド (ELP) ${ }^{28)}$ として利用されてい る。しかし，短鎖 ELP は相転移挙動を示さないため，高 分子量化が必要である。そこで，ELP をデンドリマーの 末端に結合させたエラスチンデンドリマー ${ }^{29)}$ を作製した (図 6)。そして，ペプチドの鎖長やデンドリマーの世代数

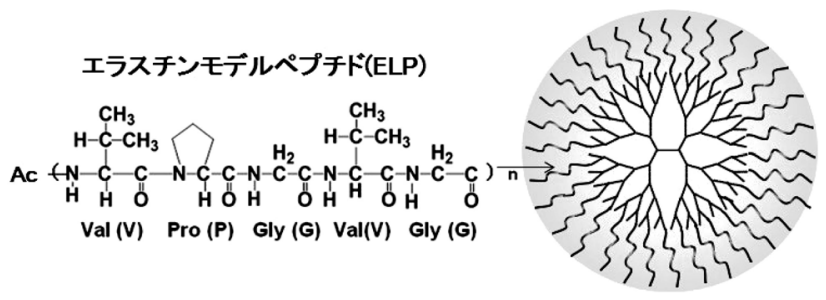

図 6 エラスチンデンドリマー.Ac はアセチル基 
表 2 鎖長や世代数の異なるエラスチンデンドリマーの相転移温度

\begin{tabular}{|c|c|c|c|c|}
\hline 化 合 物 名 & $\begin{array}{c}\text { 世 代 数 } \\
\text { (末 端 数) }\end{array}$ & ペプチド & $\begin{array}{l}\text { 分子 量 } \\
(\mathrm{kDa})\end{array}$ & $\begin{array}{c}\text { 相 転 移 温 度 } \\
\left({ }^{\circ} \mathrm{C}\right)\end{array}$ \\
\hline E L P 1 - G 4 & G 4 ( 64 ) & $A c-V P G \vee G$ & 43 & 48 \\
\hline E L P 2 - G 3 & G $3\left(\begin{array}{ll}3 & 2\end{array}\right)$ & $A c-(\vee P G \vee G)_{2}$ & 34 & 39 \\
\hline E L P 2 - G 4 & G 4 ( 64 ) & $A C-(\vee P G \vee G)_{2}$ & 69 & 38 \\
\hline E L P 2 - G 5 & G $5\left(\begin{array}{lll}12 & 8\end{array}\right)$ & $A C-(V P G \vee G)_{2}$ & 139 & 30 \\
\hline
\end{tabular}

がその温度応答性に与える影響について検討するため, G3 から G5 の PAMAM デンドリマーにVPGVG（ELP1） および (VPGVG) 2 (ELP2) を結合させた様々なエラスチ ンデンドリマーを合成した（ELP1-G4, ELP2-G3, ELP2 -G4, ELP2-G5)。これらのデンドリマーについて円二色 性 (CD) スペクトル測定を行ったところ，加温によりラン ダムコイル構造から $\beta$ ターン構造へ変化することが示唆さ れた。対応する ELP では同様の CD パターンが見られた ことから，デンドリマーへの結合はエラスチンペプチドの 性質に影響を与えないことが示唆された。次に, 温度変化 濁度測定によって相転移挙動を検討した。それぞれのデン ドリマーの相転移温度を表 2 に示す。ペプチド単独では相 転移挙動は見られなかったが，エラスチンデンドリマーで は加温によって相転移挙動が見られた。以上より，エラス チンデンドリマーではデンドリマー表面のペプチドの二次 構造变化によって疎水性が増加し，デンドリマーが凝集す る相転移が生じたと考えられる。そして, エラスチンデン ドリマーのペプチド鎖長の伸長や世代数の増加によって,

相転移温度を低下させることができた。また，ELP2-G3 及び ELP2-G4 はバイオ応用に適する体温付近で相転移 することがわかった。

そこで，このエラスチンデンドリマーを金ナノ粒子の運 搬体として用いることにした。金ナノ粒子は光照射により 発熱する性質を示し，光温熱療法に応用されている30)。図 3 に示すと扣り PEG 修飾 PAMAM デンドリマーには金 ナノ粒子を内包させることができるので ${ }^{16)}$ ，この手法を エラスチンデンドリマーに展開することで，金ナノ粒子を 担持したエラスチンデンドリマー31)を作製した。そして， このデンドリマーが温度応答性と光応答性を併せ持つ二重 刺激応答性ナノ粒子として機能することを明らかにした。 金は位相差像で黒色物として観察することができる。図 7 に示すように, PEG 修飾デンドリマーでは金ナノ粒子は 細胞にはほとんど取り込まれなかったが，エラスチンデン ドリマーでは多くの金ナノ粒子を細胞に取り込まれせるこ とができた。そして，エラスチンデンドリマーを用いるこ
位相差像

(A)

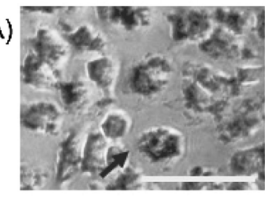

(B)

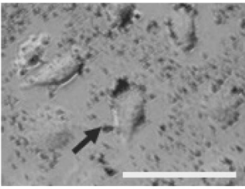

(C)

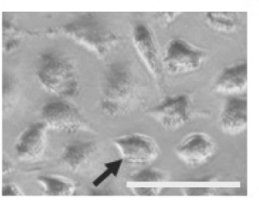

生細胞
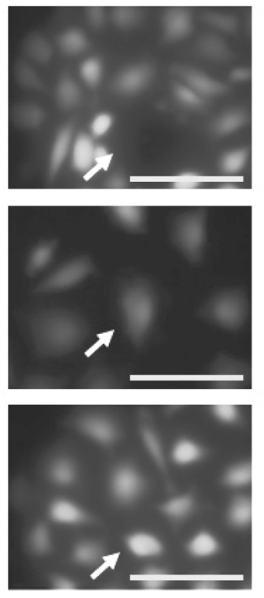

死細胞
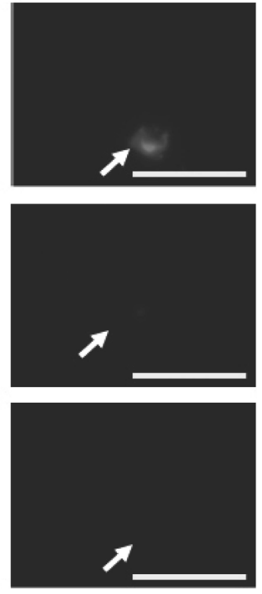

図 7 金ナノ粒子を担持したエラスチンデンドリマー $\left(37^{\circ} \mathrm{C}(\mathrm{A})\right.$ と $\left.25^{\circ} \mathrm{C}(\mathrm{B})\right)$ と $\mathrm{PEG}$ 修飾デンドリマー (C) の細胞への取り込みと光細胞毒性実験の比較. 矢印は光照射した細胞を示しており，カルセイン - AM とヨウ化プロピジウムを用い, 生細胞を緑色 に，死細胞を赤色に染色した

とで, 効果的な光細胞毒性を発現させることができた。ま た，エラスチンデンドリマーでは，低温にすると金ナノ粒 子の細胞への取り込みを抑制することができ，温度によっ て細胞への取り込みをスイッチングできることが明らかと なった。

\section{6. おわりに}

本稿では, DDS 分野に扔けるデンドリマーの有用性や 細胞や組織への接着を制御するための表面修飾に関して記 載した。バイオ材料は, DDS 分野以外にも様々な分野で利 用されており，その用途によって細胞や蛋白質との接着を (1)抑制したいむの，(2)促進したいもの，(3)スイッチングし たいあのに分類される。したがって, 目的の用途, 標的之 なる細胞や組織の特性をよく理解して，それに適した材料 を設計・作製することが必要である。本稿が「Adhesion」 研究における異分野融合を促進し，新規マテリアルの創製 につながる足がかりになれば幸いである。 


\section{文献}

1) D. A. Tomalia, A. M. Naylor, and W. A. Goddard, Angew. Chem. Int. Ed. Eng., 29, 138 (1990).

2) D. Astruc, E. Boisselier, and C. Ornelas, Chem. Rev., 110, 1857 (2010)

3) S. Svenson, and D. A. Tomalia, Adv. Drug. Deliv. Rev., 57, 2106 (2005)

4）览島千恵，高分子， 62, 325 (2013).

5) C. Kojima, "Design of Stimuli-Responsive Dendrimers for Biomedical Purposes" Dendrimer-Based Drug Delivery System: From Theory to Practice, Wiley, p. 307 (2012).

6) C. Kojima, "Smart Dendrimers", Smart Materials for Drug Delivery, Royal Society of Chemistry, p. 94 (2013).

7）“絵で見てわかるナノDDS一マテリアルから見た治療・診 断・予後・予防，ヘルスケア技術の最先端一”，メディカル ドゥ (2007).

8) L. Albertazzi, M. Serresi, A. Albanese, and F. Beltram, Mol. Pharm., 7, 680 (2010).

9) H. Maeda, J. Wu, T. Sawa, Y. Matsumura, and K. Hori, J. Control. Release, 122, 39 (2007).

10) F. Alexis, E. Pridgen, L. K. Molnar, and O. C. Farokhzad, Mol. Pharm., 5, 505 (2008).

11) S. Sadekar, A. Ray, M. Janat-Amsbury, C. M. Peterson, and H. Ghandehari, Biomacromolecules, 12, 88 (2011).

12) R. B. Greenwald, C. D. Conover, and Y. H. Choe, Crit. Rev. Ther. Drug. Carrier. Syst., 17, 101 (2000).

13) C. Kojima, K. Kono, K. Maruyama, and T. Takagishi, Bioconjug. Chem., 11, 910 (2000).

14) C. Kojima, Y. Toi, A. Harada, and K. Kono, Bioconjug. Chem., 18, 663 (2007).
15） C. Kojima, Y. Toi, A. Harada, and K. Kono. Bioconjug. Chem., 19, 2280 (2008).

16) Y. Haba, C. Kojima, A. Harada, T. Ura, H. Horinaka, and K. Kono, Langmuir, 23, 5243 (2007).

17) C. Kojima, C. Regino, Y. Umeda, H. Kobayashi, and K. Kono, Int. J. Pharm., 383, 293 (2010).

18) H. Hatakeyama, H. Akita, and H. Harashima, Adv. Drug Deliv. Rev., 63, 152 (2011).

19) R. Q. Huang, Y. H. Qu, W. L. Ke, J. H. Zhu, Y. Y. Pei, and C. Jiang, FASEB J., 21, 1117 (2007).

20) L. Han, R. Huang, S. Liu, S. Huang, and C. Jiang, Mol. Pharm., 7, 2156 (2010).

21) P.Singh, U.Gupta, A. Asthana, and N.K. Jain, Bioconjug. Chem., 19, 2239 (2008).

22) D. Schmaljohann, Adv. Drug Deliv. Rev., 58, 1655 (2006).

23) M. Kimura, M. Kato, T. Muto, K. Hanabusa, and H. Shirai, Macromolecules, 33, 1117 (2000).

24) Y. Haba, C. Kojima, A. Harada, and K. Kono, Angew. Chem. Int. Ed., 46, 234 (2007).

25) Y. Haba, C. Kojima, A. Harada, and K. Kono, Macromolecules, 39, 7451 (2006).

26) K. Kono, T. Miyoshi, Y. Haba, E. Murakami, C. Kojima, and A. Harada, J. Am. Chem. Soc., 129, 7222 (2007).

27) Y. Tono, C. Kojima, Y. Haba, T. Takahashi, A. Harada, S. Yagi, and K. Kono, Langmuir, 22, 4920 (2006).

28) D. W. Urry, K. D. Urry, W. Szaflarski, and W. Nowicki, Adv. Drug Deliv. Rev., 62, 1404 (2010).

29) C. Kojima, K. Irie, T. Tada, and N. Tanaka, Biopolymers, 101, 603 (2014)

30) M.-C. Daniel and D. Astruc, Chem. Rev., 104, 2913 (2014).

31) D. Fukushima, U. H. Sk, Y. Sakamoto, I. Nakase, and C. Kojima, Coll. Surf B, 132, 155 (2015). 